Article

\title{
Toxic Effects of Bisphenol A, Propyl Paraben, and Triclosan on Caenorhabditis elegans
}

\author{
María Cecilia García-Espiñeira ${ }^{1}$, Lesly Patricia Tejeda-Benítez ${ }^{2}$ and Jesus Olivero-Verbel ${ }^{1, * \text { (i) }}$ \\ 1 Environmental and Computational Chemistry Group, School of Pharmaceutical Sciences, University of \\ Cartagena, Zaragocilla Campus, Cartagena 130015, Colombia; mgarciae@unicartagena.edu.co \\ 2 Biological, Toxicological and Environmental Sciences Research Group, School of Medicine, University of \\ Cartagena, Zaragocilla Campus, Cartagena 130015, Colombia; 1tejedab@unicartagena.edu.co \\ * Correspondence: joliverov@unicartagena.edu.co; Tel.: +57-318-535-9815
}

Received: 20 February 2018; Accepted: 30 March 2018; Published: 5 April 2018

\begin{abstract}
Bisphenol A (BPA) is a ubiquitous plasticizer which is absorbed by ingestion and dermal contact; propyl paraben (PPB) inhibits the microbiome and extends the shelf life of many personal care products, whereas triclosan (TCS) is commonly found in antiseptics, disinfectants, or additives. In this work, Caenorhabditis elegans was used as a biological model to assess the toxic effects of BPA, PPB, and TCS. The wild type strain, Bristol N2, was used in bioassays with the endpoints of lethality, growth, and reproduction; green fluorescent protein (GFP) transgenic strains with the $h s p-3, h s p-4$, $h s p-16.2, h s p-70$, sod-1, sod-4, cyp-35A4, cyp-29A2, and skn-1 genes were evaluated for their mRNA expression through fluorescence measurement; and quick Oil Red O (q ORO) was utilized to stain lipid deposits. Lethality was concentration-dependent, while TCS and PPB showed more toxicity than BPA. BPA augmented worm length, while PPB reduced it. All toxicants moderately increased the width and the width-length ratio. BPA and PPB promoted reproduction, in contrast to TCS, which diminished it. All toxicants affected the mRNA expression of genes related to cellular stress, control of reactive oxygen species, and nuclear receptor activation. Lipid accumulation occurred in exposed worms. In conclusion, BPA, PPB, and TCS alter the physiology of growth, lipid accumulation, and reproduction in C. elegans, most likely through oxidative stress mechanisms.
\end{abstract}

Keywords: emerging contaminants; Bisphenol A; propyl paraben; triclosan; Caenorhabditis elegans

\section{Introduction}

Endocrine-disrupting chemicals (EDCs) are natural or synthetic compounds and are called xenoestrogens because of their capability to disrupt endocrine functions by mimicking or blocking endogenous hormones [1,2]. For many years, EDCs have been widely introduced into the environment and to the human food chain, exposing living organisms to their actions [3,4]. Among the EDCs, bisphenol A, propyl paraben, and triclosan are some of the most important chemicals due to their extended use.

Bisphenol A (2,2-bis (4-hydroxyphenyl) propane) (BPA) is widely used in the production of polycarbonate plastics, epoxy resins, thermal paper, paints, water-pipes, electronic equipment, toys, packaging, bottles, medical devices, surface coatings, printing inks, flame retardants, laptops, mobile phones, electronic devices, dental sealants, and laboratory and hospital equipment, among others [5-9]. Some of these applications were the causes of human exposure to BPA through food and drinks [10,11], or by inhalation and dermal contact [12-14]. Furthermore, due to its wide range of industrial uses, $\mathrm{BPA}$ is released into the environment, raising concerns regarding aquatic and terrestrial ecosystems as BPA is now present in surface water, atmospheric dust, sediment, and biota [14-16]. BPA has been identified in house dust at concentrations between 0.2 and $17.6 \mu \mathrm{g} / \mathrm{g}$, in air samples at an 
average concentration of $0.51 \mathrm{ng} / \mathrm{m}^{3}$, and in air samples from workplace plastics $\left(208 \mathrm{ng} / \mathrm{m}^{3}\right)$ [17] at concentrations of $2.4-3.59 \mathrm{ng} / \mathrm{m}^{3}$ [18]. In human hair, the mean BPA concentration amounts to $411.2 \mathrm{ng} / \mathrm{g}$ [19].

BPA binds to various receptors such as estrogen and androgen, aryl hydrocarbon receptor (AhR), and peroxisome proliferator-activated receptor (PPAR), all of which are associated with the endocrine system [20]. Moreover, BPA is able to disrupt the function of sex hormones, leptin, insulin, and thyroxin. It is also known that, even at a nanomolar level, BPA is able to induce genotoxic, mutagenic, hepatotoxic, immunotoxic, neurotoxic, teratogenic, and carcinogenic effects [21,22]. More recently, it has been suggested that BPA increases the risk of obesity, diabetes, and heart disease in humans and is related to epigenetic modifications [9,23-26].

Parabens are alkyl esters of $p$-hydroxybenzoic acid, an excellent preservative with antimicrobial activity, and they are used to control molds and yeasts in food, beverages, and cosmetic and pharmaceutical products due to their relatively low toxicity and safety $[27,28]$. Human exposure to parabens may take place through ingestion, inhalation, or dermal absorption, and several parabens have been suggested to interfere with endocrine signaling and to stimulate adipocyte differentiation [29]. Propyl $p$-hydroxybenzoate, commonly referred to as propyl paraben (PPB), is a member of this family which most inhibits microbial growth and extends the shelf life of a range of consumer products [30]. PPB is a stable molecule over the $\mathrm{pH}$ range, and it is soluble enough in water to produce an effective concentration in an aqueous phase [31]. It is readily biodegradable under aerobic conditions, and its potential for bioaccumulation is low to moderate due its low octanol-water partition coefficient $[32,33]$. It is known that the estrogenic effect of PPB is approximately 10,000-fold lower than $17 \beta$-estradiol, but is equal in potency to 4-nonylphenol [34]. Despite the fact that parabens are considered relatively safe compounds with a low bioaccumulation potential [35], their detection in human fluids [36-41] and human tumors [42,43] have demonstrated in several in vivo and in vitro screening tests that parabens have endocrine-disrupting activity that may represent a potential risk to human health [44-46]. PPB was detected in human urine at concentrations of $75.3 \mu \mathrm{g} / \mathrm{L}$ and in cord blood plasma samples at concentrations below $0.27 \mu \mathrm{g} / \mathrm{L}$ [47]. PPB may alter the viability of human sperm, and in animals, some studies showed that its exposure stimulates cell proliferation in the forestomach of rats $[48,49]$. Meanwhile, a study involving hamsters reported that PPB augmented the labeling index of their urinary bladder epithelium [50]. In addition, other investigations have concluded that exposure of rats and mice to PPB negatively affected the secretion of testosterone [51] and caused significant vitellogenin induction in male rainbow trout, [52] in medaka [53], and in Danio Rerio [54]. Consequently, the unwitting and continued exposure of this preservative exerts deleterious effects on humans and environmental health.

Triclosan (TCS) is widely used in personal care products such as antiseptics and disinfectants, or in additives used in clinical applications, cosmetics, household cleaners, plastics, paints, and textiles, among others. TCS has been detected in environmental samples such as waters, sediments, and soils. Due to its extensive use, persistence, low water solubility, and high octanol-water partition coefficient, TCS can accumulate in soils and sediments, and it has been found in wastewaters, surface waters, sediments and biological samples [55], and wastewater treatment effluents [56,57]. For instance, in fish muscle, TCS concentrations have been registered at $<0.2-3.4 \mathrm{ng} / \mathrm{g}$ [58]. Underground water has been reported to have up to $0.10 \mathrm{nM}$ TCS [59], whereas untreated surface waters had reported concentrations between 7.9 and $39 \mathrm{nM}$ [60]. At high concentrations, TCS is a biocide with several cytoplasmic and membrane targets, whereas at minor concentrations found in commercial products, it inhibits bacterial fatty acid synthesis [61].

Some studies have reported the toxicity of TCS in different organisms, including Daphnia magna [62-64] Thamnocephalus platyurus [65], Ampelisca abdita, Americamysis bahia [66], Artemia salina [67], Eisenia fetida [30,68,69], Achatina fulica [70] Dreissena polymorpha [71], Chironomus riparius [72-74], Chlorococcum sp. [75], Chlamydomonas reinhardtii [74], Gammarus pulex [76], Tigriopus japonicas [77], Bufo gargarizans [78], and Chlamydomonas reinhardtii [79], among others. 
These studies have been related to several toxicity endpoints and mechanisms such as oxidative stress and changes in gene expression. Some authors studied the effects of TCS as an endocrine disruptor; for instance, studies on Chironomus riparius showed that TCS may alter the transcriptional activity of endocrine-related genes [74]. In bioassays using Daphnia magna, TCS induced a significant decrease in the number of neonates [64]. Moreover, TCS reduced the fecundity of Tigriopus japonicas [77] and has been associated with alterations in the endocrine function in humans [80]. More recently, it has been reported that TCS causes an acute toxicity in C. elegans and also an induced reduction in its reproduction, lifespan, and delay in its hatching [81].

In this work, the nematode Caenorhabditis elegans was used as a biological model to assess the toxic effects of BPA, PPB, and TCS. This organism is widely used as a model to assess the toxicity of several compounds such as metals [82,83], pesticides [84], nanoparticles [85,86], and emerging pollutants [87]. C. elegans has been a popular biological model that has been used to investigate the effects of toxicants through several endpoints such as body length, development, and brood size, among others [88], and it is an excellent model to evaluate reproductive toxicity [89]. Lethality was used to establish the sublethal concentrations of these compounds. Growth, reproduction, changes in gene expression, and lipid accumulation were endpoints selected to analyze endocrine disruption.

\section{Materials and Methods}

\subsection{Nematodes and Bacteria}

The C. elegans wild-type strain Bristol N2 was used in the bioassays of growth and fertility. Green fluorescent protein (GFP) transgenic nematodes integrated to genes coding for heat shock proteins ( $h s p-3, h s p-4, h s p-16.2$, and $h s p-70)$, antioxidant enzymes (sod-1 and sod-4), biotransformation enzymes (cyp-35A4 and cyp-29A2), and transcription factor (skn-1), were used to determine changes in gene expression. Escherichia coli OP50 was used as nourishment in $\mathrm{K}$ agar that was prepared with $\mathrm{KCl}$, $\mathrm{NaCl}$, agar, peptone, cholesterol, $\mathrm{CaCl}_{2}$, and $\mathrm{MgSO}_{4}$. An age-synchronized population of worms was obtained by bleaching them in an alkaline solution [39].

\subsection{Solutions and Exposure}

The reagents that were purchased from Sigma Aldrich were BPA (CAS Number 80-05-7; Sigma, St. Louis, MO, USA), PPB (CAS Number 94-13-3; St. Louis, MO, USA), and TCS (CAS Number 3380-34-5; Sigma, St. Louis, MO, USA). The structural formula of each compound is displayed in Figure 1. Age-synchronized nematodes were exposed to $0.05-5000 \mu \mathrm{M}$ of each compound. A K medium ( $\mathrm{NaCl} 52 \mathrm{mM}$ and $\mathrm{KCl} 32 \mathrm{mM}$ in ultra-filtered water) [39] was utilized as a solvent and as a control. Four replicates were performed per sample, and each experiment was repeated three times.

A.

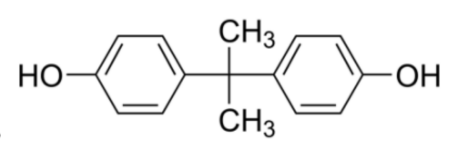

B.

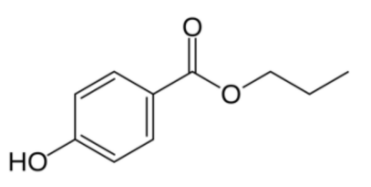

C.<smiles>Oc1cc(Cl)ccc1Oc1ccc(Cl)cc1Cl</smiles>

Figure 1. Structural formula of pollutants. (A) Bisphenol A; (B) Propyl paraben; (C) Triclosan.

\subsection{Lethality Assay}

Nematodes in the L4-larval stage were exposed to toxic solutions. Approximately $10 \pm 1$ worms were used for treatment. After $24 \mathrm{~h}$, the number of live and dead worms was counted through visual inspection using a dissecting microscope. Worms were scored as dead when physical stimuli failed to generate any response $[39,90]$. 


\subsection{Growth Assay}

The growth of nematodes was assessed in larval age L1 after $48 \mathrm{~h}$ exposure to toxic solutions. E. coli OP50 was inoculated as a source of food. After their exposure to toxic solutions, the nematodes were heated to $50{ }^{\circ} \mathrm{C}$, and this aimed to make their bodies adopt a straight line. Body length and width were then measured by analyzing a photograph recorded by a dissecting microscope and using the software Image J. The width and body length ratio (WBR) was estimated as the quotient between the body length and the width. About 30 nematodes were examined per treatment [91-94].

\subsection{Reproduction Assay}

Nematodes previously exposed for $24 \mathrm{~h}$ to toxic solutions were set individually in $\mathrm{K}$ agar plates seeded with E. coli OP50, and the number of offspring at all stages was counted after $24 \mathrm{~h}$. About 10 nematodes were examined per treatment [95-98].

\subsection{Gene Expression through Fluorescence Measuring}

The effects on gene expression were monitored utilizing GFP transgenic C. elegans strains containing the $h s p-3, h s p-70$, sod-1, sod-4, gpx-4, and $g p x-6$ genes. Equal aliquots of nematodes on all larval stages were placed into black, non-fluorescent, U-bottomed, 96-well microplates with the toxic solutions of BPA, TCS, and PPB. The plates were incubated at $15{ }^{\circ} \mathrm{C}$, and after $24 \mathrm{~h}$, the fluorescence intensity was quantified using a plate reader (Fluoroskan Ascent, Thermo Scientific, Waltham, MA, USA) with excitation/emission filters of 485/525 nm [99-103]. The relative fluorescence was calculated as the quotient between the solution's fluorescence and that of the control [90].

\section{7. q-ORO Assay}

The q-ORO assay was done as described [104]. Age-synchronized Bristol N2 wild type nematodes in the L4-larval stage were exposed for $24 \mathrm{~h}$ to toxic solutions of BPA, PPB, and TCS. To prepare the dye solution, a $0.5 \%$ oil red O (MP, Cat. No. 155984) stock solution was prepared in high-quality $100 \%$ isopropanol, incubated at room temperature for a day, and then filtered through a $0.45 \mu \mathrm{m}$ filter. The stock was freshly diluted to $60 \%$ with filtered water the day before its use, and it was then incubated at room temperature overnight. The stock was filtered through a $0.45 \mu \mathrm{m}$ filter. Two hundred microliters of high-quality $60 \%$ isopropanol was added to the worms in the 96-well PCR plates (Thermo Scientific, Waltham, MA, USA). Worms were settled to the bottom of the wells, and then they were aspirated with up to $175 \mu \mathrm{L}$ of buffer. Two hundred microliters of freshly filtered ORO working solution was added, which sealed the plates. Worms were stained for $6-18 \mathrm{~h}$ at $25^{\circ} \mathrm{C}$; after $6-18 \mathrm{~h}$, the supernatant was aspirated. Then, $100 \mu \mathrm{L}$ of $0.01 \%$ Triton $\mathrm{X}-100$ was added in the $\mathrm{S}$ buffer. Images were recorded by using an optic microscope [104].

\subsection{Statistical Analysis}

Data are presented as mean \pm standard error. Normality and variance homogeneity were verified using the Kolmogorov-Smirnov and the Bartlett tests, respectively. Significant differences between means were determined with one-way analysis of variance (ANOVA) test. The Dunnett test was applied to compare each solution with the control. The significance level or criterion of significance was set at $p<0.05$. Statistical analyses were performed with SPSS for Windows (Version 23, Statistical Package for the Social Sciences, Inc., Chicago, IL, USA) and Graphpad Prism (Version 5.0, GraphPadSoftware, San Diego, CA, USA). 


\section{Results}

\subsection{Lethality}

The results of the lethality bioassay are displayed in Figure 2. The lethality was concentration-dependent, and the LC50 after $24 \mathrm{~h}$ exposure for BPA, PPB, and TCS were 113.5, 261.7, and $43.2 \mu \mathrm{M}$, respectively (Table S1). At concentrations greater than $0.5 \mu \mathrm{M}$, all compounds caused lethality, with statistical differences being related to the control. At lower concentrations, only TCS $(0.05 \mu \mathrm{M})$ was bioactive.

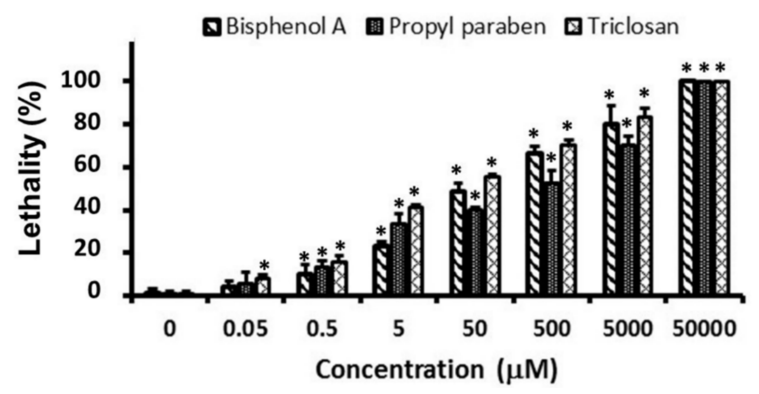

Figure 2. Lethality of C. elegans exposed to bisphenol A, propyl paraben, and triclosan. * Significant difference compared to control $(p<0.05)$.

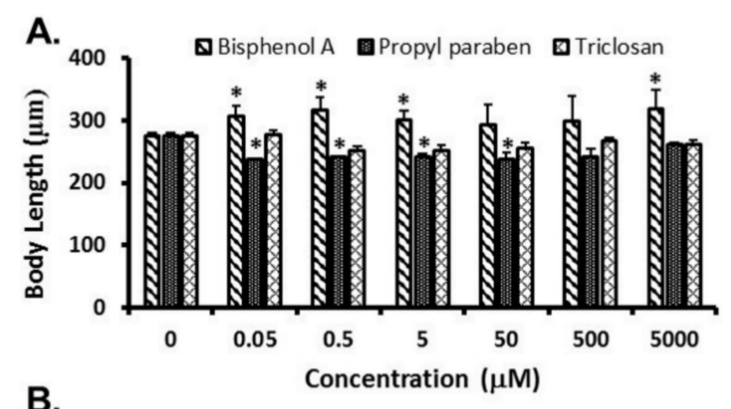

B.
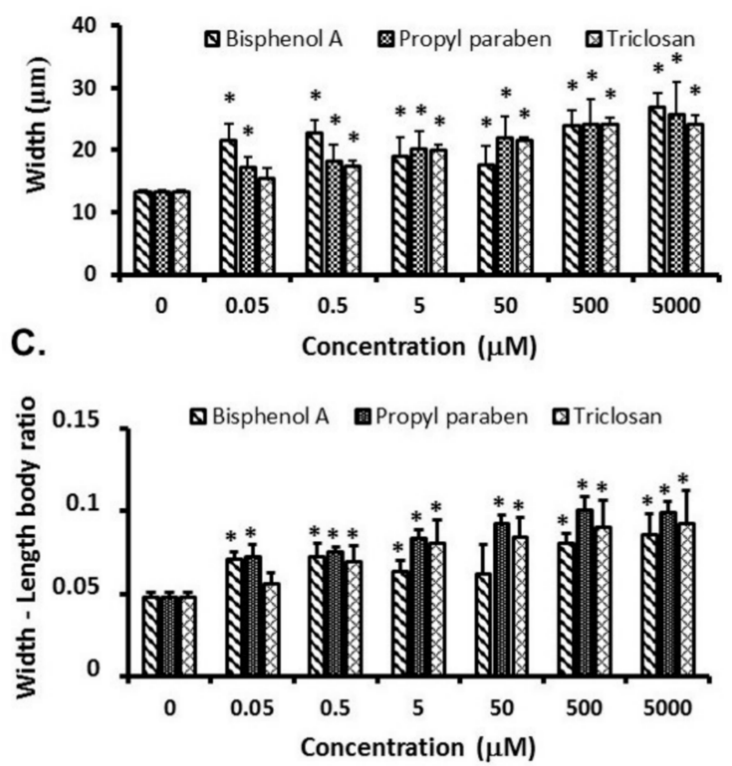

Figure 3. Changes in body length (A), width (B), and width/length ratio (C) in C. elegans exposed to bisphenol A, propyl paraben, and triclosan. * Significant difference compared to control $(p<0.05)$. 


\subsection{Growth}

Changes in the body length, the body width, and the body width-length ratio of nematodes exposed to BPA, PPB, and TCS solutions are shown in Figure 3. Body length was slightly increased by BPA but was not concentration-dependent. In contrast, PPB reduced the body length, while TCS did not have an effect on this parameter. All the toxic chemicals moderately increased the body width, without a clear relationship with concentration, although the response elicited by BPA was bimodal. The relation between the body width and the body length of the nematodes was moderately increased by an exposure to the tested chemicals, but PPB was the most active, suggesting a probable association with obesity in the C. elegans model.

\subsection{Reproduction}

The brood size of nematodes exposed to BPA, PPB, and TCS solutions are shown in Figure 4. The greatest brood size after BPA exposure was reached at $5 \mu \mathrm{M}$; afterwards, it decreased in response to higher concentrations. Similarly, PPB increased the brood size until $0.5 \mu \mathrm{M}$, with declining effects at greater concentrations. In contrast, TCS decreased the brood size following a concentration-dependent trend.

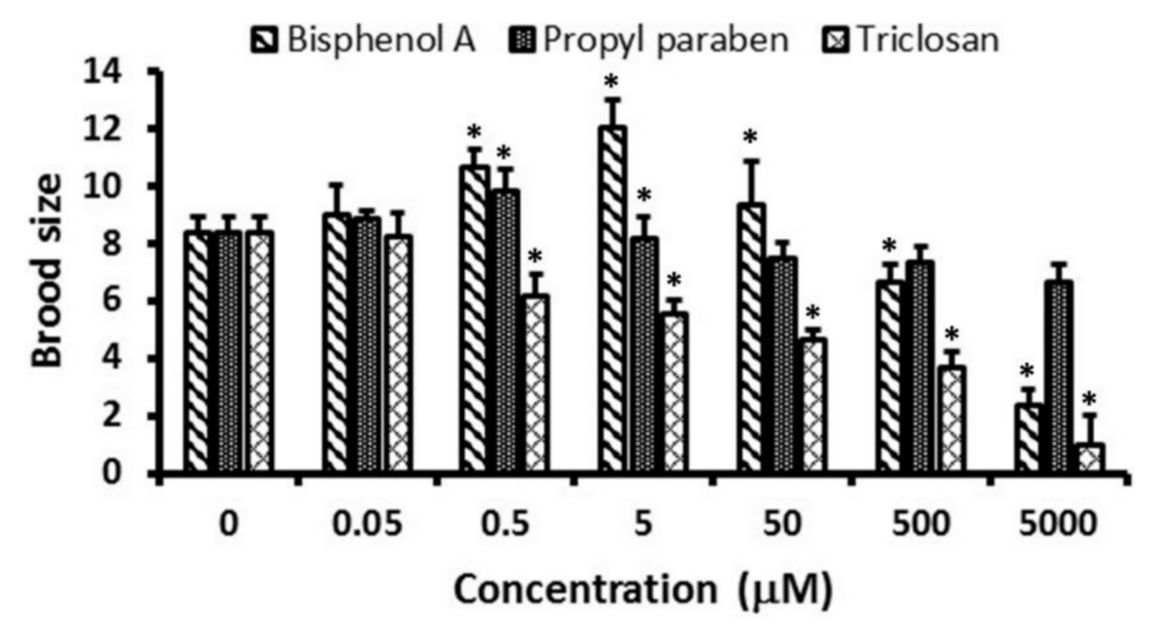

Figure 4. Brood size of C. elegans exposed to bisphenol A, propyl paraben, and triclosan solutions.

* Significant difference compared to control $(p<0.05)$.

\subsection{Changes in Gene Expression}

The relative changes in gene expression in C. elegans carrying gfp-reporter genes are displayed in Figure 5, and graphs are presented in Figures S1-S9 in Supplementary Material. The most sensitive genes, in descending order, were sod-4, $h s p-4, h s p-16.2$, and $s k n-1$. These genes increased their expression after their exposure to all the compounds, indicating a toxic response related to the generation of reactive oxygen species (ROS). There was no evidence of concentration dependence in these results. Furthermore, low concentrations caused the overexpression of some genes; for instance, BPA at concentrations of 0.05 and $0.5 \mu \mathrm{M}$ caused a 3 -fold expression of $h s p-4$. However, high concentrations also affected the expression of several genes such as sod-4, which showed a 5 -fold upregulation after its exposure to PPB and TCS at concentrations of $500 \mu \mathrm{M}$ when compared to the control. 


\begin{tabular}{|c|c|c|c|c|c|c|c|c|c|c|}
\hline Compound & Concentration $(\mu \mathrm{M})$ & hsp-3 & $h s p-4$ & hsp-16.2 & hsp-70 & sod-1 & sod-4 & сур-29A2 & сур-34A9 & $s k n-1$ \\
\hline \multirow{6}{*}{ BPA } & 0.05 & & & & & & & & & \\
\hline & 0.5 & & & & & & & & & \\
\hline & 5 & & & & & & & & & \\
\hline & 50 & & & & & & & & & \\
\hline & 500 & & & & & & & & & \\
\hline & 5000 & & & & & & & & & \\
\hline \multirow{6}{*}{ PPB } & 0.05 & & & & & & & & & \\
\hline & 0.5 & & & & & & & & & \\
\hline & 5 & & & & & & & & & \\
\hline & 50 & & & & & & & & & \\
\hline & 500 & & & & & & & & & \\
\hline & 5000 & & & & & & & & & \\
\hline \multirow{6}{*}{ TCS } & 0.05 & & & & & & & & & \\
\hline & 0.5 & & & & & & & & & \\
\hline & 5 & & & & & & & & & \\
\hline & 50 & & & & & & & & & \\
\hline & 500 & & & & & & & & & \\
\hline & 5000 & & & & & & & & & \\
\hline
\end{tabular}

Figure 5. Changes in the mRNA expression profiles of evaluated genes measured in relation to control. Blue: <2-fold; Green: 2-3-fold; Yellow: 3-4-fold; Orange: 4-5-fold; Red: >5-fold.

\section{5. q-ORO Stain}

Representative images of nematodes that were exposed to the BPA, PPB, and TCS solutions and stained with q-ORO are displayed in Figure 6. All the tested chemicals caused lipid deposition inside the bodies of exposed nematodes. According to the intensity of the color recorded in the images, the deposits formed show an increasing trend related to concentration. BPA caused more lipid accumulation, followed by PPB and TCS. This result is consistent with the changes in the body width-length ratio that were registered in the worms after their exposure to these molecules.

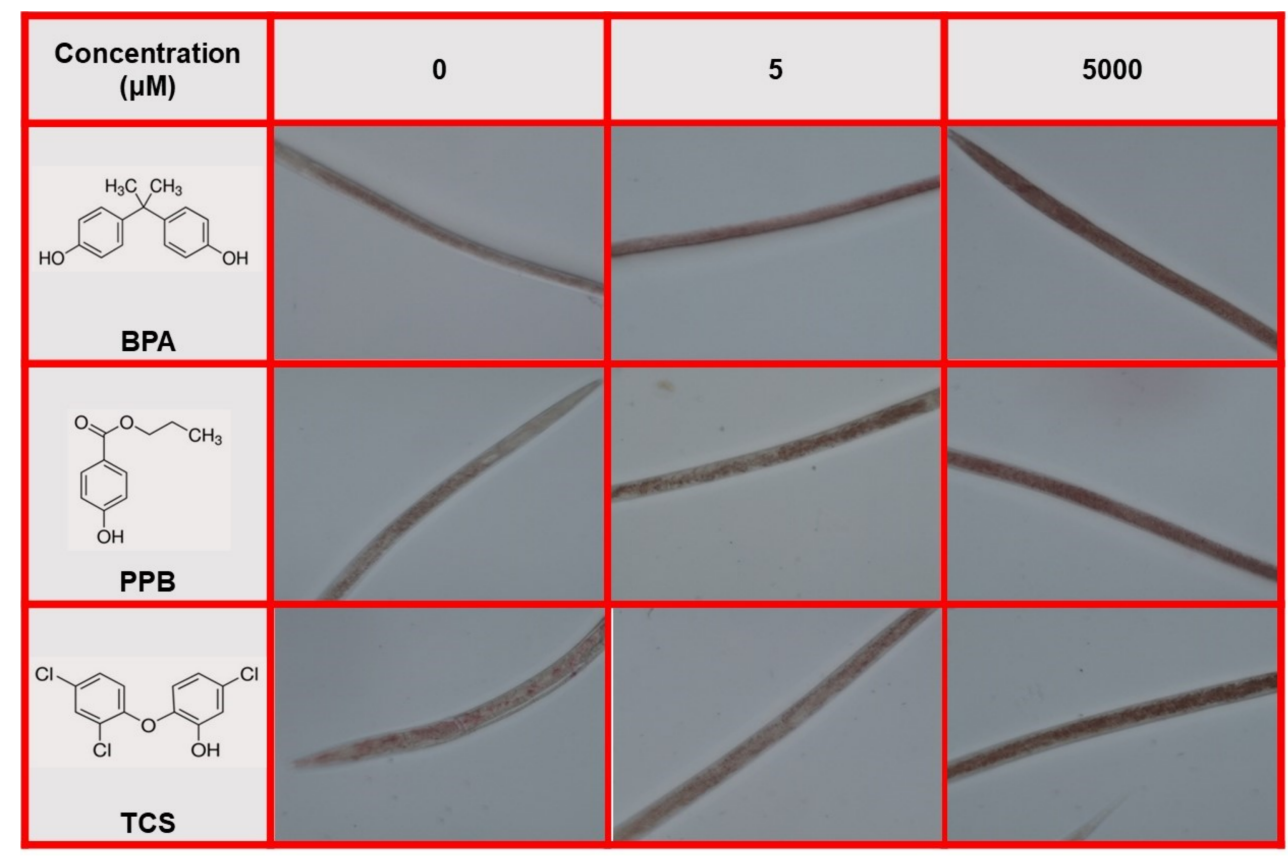

Figure 6. q-ORO staining of nematodes exposed to BPA, PPB, and TCS.

\section{Discussion}

Exposure to BPA, PPB, and TCS alters the physiology of C. elegans in terms of growth, reproduction, and gene expression. In this work, TCS exerted the greatest acute toxicity on C. elegans, followed by BPA and PPB. There is extensive information on BPA toxicity for several organisms. For example, in the snail, Pomacea lineata, the $96 \mathrm{~h} \mathrm{LC50} \mathrm{was} 11.1 \mathrm{mg} / \mathrm{L}$ [105], whereas in the sea squirt, Ciona intestinalis, the 
LC50 was $5.4 \mu \mathrm{M}$ [106]. Other authors have also reported toxicity data for BPA on C. elegans, with a $24 \mathrm{~h}$ LC50 value of $1422 \mu \mathrm{M}$ (324.7 mg/L) [107]. However, they used 1-day-old (L1/L2) larvae, which may explain the observed difference in the order of magnitude in toxicity. Propyl paraben was less toxic than BPA, although organisms such as D. magna and Pimephales promelas were more sensitive to PPB exposure than C. elegans, with LC50 values of $12.3 \mathrm{mg} / \mathrm{L}$ and $9.7 \mathrm{mg} / \mathrm{L}$, respectively [108]. Finally, the $24 \mathrm{~h}$ LC50 for TCS was $43.2 \mu \mathrm{M}(9.84 \mathrm{mg} / \mathrm{L})$, comparable to $3.65 \mathrm{mg} / \mathrm{L}$ as previously reported [81]. Other model organisms, such as Artemia salina, Thamnocephalus platyurus, and Chironomus riparius have showed LC50 values after $24 \mathrm{~h}$ exposure of 171, 470, and $3428 \mu \mathrm{g} / \mathrm{L}$ TCS, respectively $[65,67,74]$.

The effect of BPA on the growth of $C$. elegans varied according to the level of exposure, and as presented here, the concentration-response relationship is not always monotonic [109,110]. The effects of PPB and TCS have not been reported yet on the growth of C. elegans. However, other organisms have been tested; for example, TCS at a level below $0.8 \mu \mathrm{M}$ did not have significant effects on the body length of D. magna [62]. In regards to PPB, the lowest concentration associated with the growth of C. elegans that has had an observed effect has been estimated to be $0.4 \mathrm{mg} / \mathrm{L}(2.2 \mu \mathrm{M})$ for D. magna and $2.5 \mathrm{mg} / \mathrm{L}(13 \mu \mathrm{M})$ for P. promeras [108].

The reproductive outcome of $C$. elegans after its exposure to tested chemicals suggests that endocrine disruption had occurred. For instance, the effect of BPA on nematode reproduction is exemplified by a non-monotonic, inverted U-shape curve, where the effects of increasing concentrations of the compound appear to increase up to a peak and then decrease [111]. This nonlinear concentration-response relationship has also been described for some endpoints of BPA studies on C. elegans [112-114]. It has also been proven that the exposure to BPA decreases fecundity [109]. This effect and others associated with reproduction have been related to strong negative effects of this plasticizer on the germline function of $C$. elegans [114]. Although PPB induced a small increase in broad size at $0.5 \mu \mathrm{M}$, it seems to follow a slight concentration-dependent reduction in the reproduction of C. elegans. Interestingly, the effect of TCS was definitively inhibitory and dependent on concentration, as previously reported for this model [81] and also in D. magna [62].

Some studies about the changes in gene expression of $C$. elegans that were exposed to BPA have reported that the expression of $h s p-70$ exhibited a hormetic decrease, while $h s p-16.2$ showed a dose-dependent increase, which was also observed for sod-3 expression [109]. The mechanisms of action by which xenobiotics regulate Superoxide dismutase (SOD) enzymes in C. elegans are not completely elucidated. The activation of the antioxidant system in C. elegans, which includes SOD, among others, can be rather complex, and the deletion of free radicals and their toxic effects may occur through a multistep process [115]. C. elegans is highly susceptible to oxidative stress, and even its manipulation could generate stress and influence the internal redox balance [116]. The fact that all tested xenobiotics overexpress genes coding for molecules involved in the biological defense processes, such as sod-1 and sod-4, may result from the organism avoiding ROS formation. However, once ROS levels pass the required threshold, the defense against oxidative stress decreases, leading to toxicity. The activation of $h s p-70$ transcription suggests protection against protein oxidation and neuronal damage [117], which suggests that these chemicals play a role in oxidative damage.

Bisphenol A, PPB, and TCS caused the overexpression of cyp-34A9. This gene encodes monooxygenases, one of the cytochrome $\mathrm{P} 450$ proteins which catalyze reactions involved in drug metabolism and in the synthesis of steroid hormone signaling [118]. Moreover, the CYP system is one of the main targets of different nuclear xenobiotic receptors, directing different pathways of xenobiotics metabolism $[119,120]$. These processes may also have an indirect link to endocrine disruption by binding to estrogenic hormone receptors in the worm [121], especially since BPA is an estrogen-receptor ligand [122] that has been shown to transcriptionally activate the CYP2C9 promoter [123].

Bisphenol A, PPB, and TCS also up-regulated skn-1. This gene encodes the SKN-1 proteins, which are required for longevity and oxidative stress resistance in C. elegans [124]. There are indeed some similarities between the pattern expression of sod-1/sod-4 and skn-1 genes after their exposure 
to the tested compounds (Figure 5), which corresponds with the role of this gene in oxidative stress responses [125].

One of the most interesting findings in this work was that BPA, PPB, and TCS promoted lipid accumulation in $C$. elegans, a process verified through the fixation of q-ORO to lipidic deposits. An important aspect is that there are no reports of obesogenic effects, in terms of lipid accumulation, on C. elegans, as a marker of endocrine disruption elicited by these compounds. However, BPA has been recognized as an obesogen, promoting the adipogenesis, the lipid dysregulation, and the inflammation of adipose tissue [126]. It should be emphasized that more studies are needed to verify these results and the mechanisms involved in the lipid accumulation process carried out by the nematode.

\section{Conclusions}

Triclosan generated more acute toxicity than bisphenol A and propyl paraben in C. elegans. Bisphenol A and propyl paraben increased the brood size of C. elegans, and triclosan had a negative effect on reproduction. All compounds increased the expression of stress response genes such as sod-4 and $s k n-1$, which are related to the oxidative stress response; $h s p-4$ and $h s p-16.2$, which are associated with cellular stress; and other genes such as cyp-34A9, which may be a response to their interaction with nuclear xenobiotic receptors. These molecules also increased the lipid accumulation in C. elegans. Taken together, these results suggest that these chemicals promote endocrine disruption mechanisms at levels which influence reproduction and obesity.

Supplementary Materials: The following are available online at http:/ /www.mdpi.com/1660-4601/15/4/684/s1. Table S1. LC50 values and confidence limits for tested compounds after $24 \mathrm{~h}$ exposure. Figure S1. Effects of BPA, PPB and TCS on $h s p-3$ gene expression measured as GFP fluorescence. Figure S2. Effects of BPA, PPB and TCS on $h s p-4$ gene expression measured as GFP fluorescence. Figure S3. Effects of BPA, PPB and TCS on $h s p-16.2$ gene expression measured as GFP fluorescence. Figure S4. Effects of BPA, PPB and TCS on $h s p-70$ gene expression measured as GFP fluorescence. Figure S5. Effects of BPA, PPB and TCS on sod-1 gene expression measured as GFP fluorescence. Figure S6. Effects of BPA, PPB and TCS on sod-4 gene expression measured as GFP fluorescence. Figure S7. Effects of BPA, PPB and TCS on cyp-29A2 gene expression measured as GFP fluorescence. Figure S8. Effects of BPA, PPB and TCS on cyp-34A9 gene expression measured as GFP fluorescence. Figure S9. Effects of $\mathrm{BPA}, \mathrm{PPB}$ and TCS on $s k n-1$ gene expression measured as GFP fluorescence.

Acknowledgments: The authors are grateful to David De Pomerai in the University of Nottingham (UK) for supplying the transgenic strains of C. elegans; to Joel Meyer in Duke University (USA) for providing the N2 strain; to the University of Cartagena for the financial support through the Doctorate Support Program 2013-2017; and to Valeria De León-García for the language edition.

Author Contributions: All authors contributed equally to this paper.

Conflicts of Interest: The authors declare no conflict of interest.

\section{References}

1. Michałowicz, J. Bisphenol A-sources, toxicity and biotransformation. Environ. Toxicol. Pharmacol. 2014, 37, 738-758. [CrossRef] [PubMed]

2. Schug, T.T.; Janesick, A.; Blumberg, B.; Heindel, J.J. Endocrine disrupting chemicals and disease susceptibility. J. Steroid Biochem. Mol. Biol. 2011, 127, 204-215. [CrossRef] [PubMed]

3. Careghini, A.; Mastorgio, A.F.; Saponaro, S.; Sezenna, E. Bisphenol A, nonylphenols, benzophenones, and benzotriazoles in soils, groundwater, surface water, sediments, and food: A review. Environ. Sci. Pollut. Res. 2015, 22, 5711-5741. [CrossRef] [PubMed]

4. Sauvé, S.; Desrosiers, M. A review of what is an emerging contaminant. Chem. Cent. J. 2014, 8, 15. [CrossRef] [PubMed]

5. Björnsdotter, M.K.; de Boer, J.; Ballesteros-Gómez, A. Bisphenol A and replacements in thermal paper: Aa review. Chemosphere 2017, 182, 691-706. [CrossRef] [PubMed]

6. Flint, S.; Markle, T.; Thompson, S.; Wallace, E. Bisphenol A exposure, effects, and policy: A wildlife perspective. J. Environ. Manag. 2012, 104, 19-34. [CrossRef] [PubMed]

7. Hoekstra, E.J.; Simoneau, C. Release of Bbisphenol A from polycarbonate-A review. Crit. Rev. Food Sci. Nutr. 2013, 53, 386-402. [CrossRef] [PubMed] 
8. Huang, Y.Q.; Wong, C.K.C.; Zheng, J.S.; Bouwman, H.; Barra, R.; Wahlström, B.; Neretin, L.; Wong, M.H. Bisphenol A (BPA) in China: A review of sources, environmental levels, and potential human health impacts. Environ. Int. 2012, 42, 91-99. [CrossRef] [PubMed]

9. Spagnuolo, M.L.; Marini, F.; Sarabia, L.A.; Ortiz, M.C. Migration test of bisphenol A from polycarbonate cups using excitation-emission fluorescence data with parallel factor analysis. Talanta 2017, 167, 367-378. [CrossRef] [PubMed]

10. Beltifa, A.; Feriani, A.; Machreki, M.; Ghorbel, A.; Ghazouani, L.; Di Bella, G.; Van Loco, J.; Reyns, T.; Mansour, H. Ben Plasticizers and bisphenol A, in packaged foods sold in the Tunisian markets: Study of their acute in vivo toxicity and their environmental fate. Environ. Sci. Pollut. Res. 2017, 24, 22382-22392. [CrossRef] [PubMed]

11. Ndaw, S.; Remy, A.; Jargot, D.; Robert, A. Occupational exposure of cashiers to bisphenol A via thermal paper: Urinary biomonitoring study. Int. Arch. Occup. Environ. Health 2016, 89, 935-946. [CrossRef] [PubMed]

12. Hines, C.J.; Jackson, M.V.; Christianson, A.L.; Clark, J.C.; Arnold, J.E.; Pretty, J.R.; Deddens, J.A. Air, hand wipe, and surface wipe sampling for bisphenol A (BPA) among workers in industries that manufacture and use BPA in the United States. J. Occup. Environ. Hyg. 2017, 14, 882-897. [CrossRef] [PubMed]

13. Li, X.; Sun, M.-Z.; Li, X.; Zhang, S.-H.; Dai, L.-T.; Liu, X.-Y.; Zhao, X.; Chen, D.-Y.; Feng, X.-Z. Impact of low-dose chronic exposure to bisphenol A (BPA) on adult male zebrafish adaption to the environmental complexity: Disturbing the color preference patterns and reliving the anxiety behavior. Chemosphere 2017, 186, 295-304. [CrossRef] [PubMed]

14. Liu, J.; Martin, J.W. Prolonged Exposure to bisphenol A from single dermal contact events. Environ. Sci. Technol. 2017, 51, 9940-9949. [CrossRef] [PubMed]

15. Luigi, V.; Giuseppe, M.; Claudio, R. Emerging and priority contaminants with endocrine active potentials in sediments and fish from the River Po (Italy). Environ. Sci. Pollut. Res. 2015, 22, 14050-14066. [CrossRef] [PubMed]

16. Peng, Y.; Luo, Y.; Nie, X.-P.; Liao, W.; Yang, Y.-F.; Ying, G.-G. Toxic effects of triclosan on the detoxification system and breeding of Daphnia magna. Ecotoxicology 2013, 22, 1384-1394. [CrossRef] [PubMed]

17. Vandenberg, L.N.; Colborn, T.; Hayes, T.B.; Heindel, J.J.; Jacobs, D.R.; Lee, D.-H.; Shioda, T.; Soto, A.M.; vom Saal, F.S.; Welshons, W.V.; et al. Hormones and endocrine-disrupting chemicals: Low-dose effects and nonmonotonic dose responses. Endocr. Rev. 2012, 33, 378-455. [CrossRef] [PubMed]

18. Kouidhi, W.; Thannimalay, L.; Soon, C.S.; Ali Mohd, M. Occupational exposure to bisphenol A (BPA) in a plastic injection molding factory in Malaysia. Int. J. Occup. Med. Environ. Health 2017, 30, 743-750. [CrossRef] [PubMed]

19. Nehring, I.; Staniszewska, M.; Falkowska, L. Human hair, Baltic Grey Seal (Halichoerus grypus) fur and Herring Gull (Larus argentatus) feathers as accumulators of bisphenol A and alkylphenols. Arch. Environ. Contam. Toxicol. 2017, 72, 552-561. [CrossRef] [PubMed]

20. Luo, L.; Liu, M. Adipose tissue in control of metabolism. J. Endocrinol. 2016, 231, R77-R99. [CrossRef] [PubMed]

21. LaPensee, E.W.; Tuttle, T.R.; Fox, S.R.; Ben-Jonathan, N. Bisphenol A at low nanomolar doses confers chemoresistance in estrogen receptor- $\alpha$-positive and -negative breast cancer cells. Environ. Health Perspect. 2009, 117, 175-180. [CrossRef] [PubMed]

22. Pfeifer, D.; Chung, Y.M.; Hu, M.C.T. Effects of low-dose Bisphenol A on DNA damage and proliferation of breast cells: The role of c-Myc. Environ. Health Perspect. 2015, 123, 1271-1279. [CrossRef] [PubMed]

23. Mansour, S.A.; Mohamed, D.A.; Sutra, J.F. Which exposure stage (gestation or lactation) is more vulnerable to atrazine toxicity? Studies on mouse dams and their pups. Toxicol. Rep. 2014, 1, 53-68. [CrossRef] [PubMed]

24. Pu, Y.; Gingrich, J.; Steibel, J.P.; Veiga-Lopez, A. Sex-specific modulation of fetal adipogenesis by gestational Bisphenol A and Bisphenol S exposure. Endocrinology 2017, 158, 3844-3858. [CrossRef] [PubMed]

25. Rubin, B.S.; Paranjpe, M.; DaFonte, T.; Schaeberle, C.; Soto, A.M.; Obin, M.; Greenberg, A.S. Perinatal BPA exposure alters body weight and composition in a dose specific and sex specific manner: The addition of peripubertal exposure exacerbates adverse effects in female mice. Reprod. Toxicol. 2017, 68, 130-144. [CrossRef] [PubMed]

26. Wang, Y.; Hollis-Hansen, K.; Ren, X.; Qiu, Y.; Qu, W. Do environmental pollutants increase obesity risk in humans? Obes. Rev. 2016, 17, 1179-1197. [CrossRef] [PubMed] 
27. Golden, R.; Gandy, J.; Vollmer, G. A Review of the endocrine activity of parabens and implications for potential risks to human health. Crit. Rev. Toxicol. 2005, 35, 435-458. [CrossRef] [PubMed]

28. Calafat, A.M.; Ye, X.; Wong, L.-Y.; Bishop, A.M.; Needham, L.L. Urinary concentrations of four parabens in the U.S. population: NHANES 2005-2006. Environ. Health Perspect. 2010, 118, 679-685. [CrossRef] [PubMed]

29. Kodani, S.D.; Overby, H.B.; Morisseau, C.; Chen, J.; Zhao, L.; Hammock, B.D. Parabens inhibit fatty acid amide hydrolase: A potential role in paraben-enhanced 3T3-L1 adipocyte differentiation. Toxicol. Lett. 2016, 262, 92-99. [CrossRef] [PubMed]

30. Szelag, S.; Zabłocka, A.; Trzeciak, K.; Drozd, A.; Baranowska-Bosiacka, I.; Kolasa, A.; Goschorska, M.; Chlubek, D.; Gutowska, I. Propylparaben-induced disruption of energy metabolism in human HepG2 cell line leads to increased synthesis of superoxide anions and apoptosis. Toxicol. Vitr. 2016, 31, 30-34. [CrossRef] [PubMed]

31. Soni, M.G.; Burdock, G.A.; Taylor, S.L.; Greenberg, N.A. Safety assessment of propyl paraben: A review of the published literature. Food Chem. Toxicol. 2001, 39, 513-532. [CrossRef]

32. Butkovskyi, A.; Rijnaarts, H.H.M.; Zeeman, G.; Hernandez Leal, L. Fate of personal care and household products in source separated sanitation. J. Hazard. Mater. 2016, 320, 427-434. [CrossRef] [PubMed]

33. Siddique, S.; Kubwabo, C.; Harris, S.A. A review of the role of emerging environmental contaminants in the development of breast cancer in women. Emerg. Contam. 2016, 2, 204-219. [CrossRef]

34. Routledge, E.J.; Parker, J.; Odum, J.; Ashby, J.; Sumpter, J.P. Some alkyl hydroxy benzoate preservatives (parabens) are estrogenic. Toxicol. Appl. Pharmacol. 1998, 153, 12-19. [CrossRef] [PubMed]

35. Wu, C.; Huo, W.; Li, Y.; Zhang, B.; Wan, Y.; Zheng, T.; Zhou, A.; Chen, Z.; Qian, M.; Zhu, Y.; et al. Maternal urinary paraben levels and offspring size at birth from a Chinese birth cohort. Chemosphere 2017, 172, $29-36$. [CrossRef] [PubMed]

36. Ng, M.; Fleming, T.; Robinson, M.; Thomson, B.; Graetz, N.; Margono, C.; Mullany, E.C.; Biryukov, S.; Abbafati, C.; Abera, S.F.; et al. Global, regional, and national prevalence of overweight and obesity in children and adults during 1980-2013: A systematic analysis for the Global Burden of Disease Study 2013. Lancet 2014, 384, 766-781. [CrossRef]

37. Martín, J.M.P.; Peropadre, A.; Herrero, Ó.; Freire, P.F.; Labrador, V.; Hazen, M.J. Oxidative DNA damage contributes to the toxic activity of propylparaben in mammalian cells. Mutat. Res. Toxicol. Environ. Mutagen. 2010, 702, 86-91. [CrossRef] [PubMed]

38. Faniband, M.; Lindh, C.H.; Jönsson, B.A.G. Human biological monitoring of suspected endocrine-disrupting compounds. Asian J. Androl. 2014, 16, 5-16. [CrossRef] [PubMed]

39. Williams, P.L.; Dusenbery, D.B. Aquatic toxicity testing using the nematode, Caenorhabditis elegans. Environ. Toxicol. Chem. 1990, 9, 1285-1290. [CrossRef]

40. Hines, E.P.; Mendola, P.; von Ehrenstein, O.S.; Ye, X.; Calafat, A.M.; Fenton, S.E. Concentrations of environmental phenols and parabens in milk, urine and serum of lactating North Carolina women. Reprod. Toxicol. 2015, 54, 120-128. [CrossRef] [PubMed]

41. Philippat, C.; Wolff, M.S.; Calafat, A.M.; Ye, X.; Bausell, R.; Meadows, M.; Stone, J.; Slama, R.; Engel, S.M. Prenatal exposure to environmental phenols: Concentrations in amniotic fluid and variability in urinary concentrations during pregnancy. Environ. Health Perspect. 2013, 121, 1225-1231. [CrossRef] [PubMed]

42. Paulose, T.; Speroni, L.; Sonnenschein, C.; Soto, A.M. Estrogens in the wrong place at the wrong time: Fetal BPA exposure and mammary cancer. Reprod. Toxicol. 2015, 54, 58-65. [CrossRef] [PubMed]

43. Wróbel, A.M.; Gregoraszczuk, E.Ł. Action of methyl-, propyl- and butylparaben on GPR30 gene and protein expression, cAMP levels and activation of ERK1/2 and PI3K/Akt signaling pathways in MCF-7 breast cancer cells and MCF-10A non-transformed breast epithelial cells. Toxicol. Lett. 2015, 238, 110-116. [CrossRef] [PubMed]

44. Legler, J.; Fletcher, T.; Govarts, E.; Porta, M.; Blumberg, B.; Heindel, J.J.; Trasande, L. Obesity, diabetes, and associated costs of exposure to endocrine-disrupting chemicals in the european union. J. Clin. Endocrinol. Metab. 2015, 100, 1278-1288. [CrossRef] [PubMed]

45. Hu, P.; Chen, X.; Whitener, R.J.; Boder, E.T.; Jones, J.O.; Porollo, A.; Chen, J.; Zhao, L. Effects of parabens on adipocyte differentiation. Toxicol. Sci. 2013, 131, 56-70. [CrossRef] [PubMed]

46. Lee, J.H.; Lee, M.; Ahn, C.; Kang, H.Y.; Tran, D.N.; Jeung, E.B. Parabens accelerate ovarian dysfunction in a 4-vinylcyclohexene diepoxide-induced ovarian failure model. Int. J. Environ. Res. Public Health 2017, 14, 161. [CrossRef] [PubMed] 
47. Pycke, B.F.G.; Geer, L.A.; Dalloul, M.; Abulafia, O.; Halden, R.U. Maternal and fetal exposure to parabens in a multiethnic urban U.S. population. Environ. Int. 2015, 84, 193-200. [CrossRef] [PubMed]

48. Bao-Liang, S.; Hai-Ying, L.; Dun-Ren, P. In vitro spermicidal activity of parabens against human spermatozoa. Contraception 1989, 39, 331-335. [CrossRef]

49. Shibata, M.-A.; Yamada, M.; Hirose, M.; Asakawa, E.; Tatematsu, M.; Ito, N. Early proliferative responses of forestomach and glandular stomach of rats treated with five different phenolic antioxidants. Carcinogenesis 1990, 11, 425-429. [CrossRef] [PubMed]

50. Hirose, M.; Inoue, T.; Asamoto, M.; Tagawa, Y.; Ito, N. Comparison of the effects of 13 phenolic compounds in induction of proliferative lesions of the forestomach and increase in the labelling indices of the glandular stomach and urinary bladder epithelium of Syrian golden hamsters. Carcinogenesis 1986, 7, 1285-1289. [CrossRef] [PubMed]

51. Oishi, S. Effects of propyl paraben on the male reproductive system. Food Chem. Toxicol. 2002, 40, 1807-1813. [CrossRef]

52. Pedersen, K.L.; Pedersen, S.N.; Christiansen, L.B.; Korsgaard, B.; Bjerregaard, P. The preservatives ethyl-, propyl- and butylparaben are oestrogenic in an in vivo fish assay. Pharmacol. Toxicol. 2008, 86, 110-113. [CrossRef]

53. Inui, M.; Adachi, T.; Takenaka, S.; Inui, H.; Nakazawa, M.; Ueda, M.; Watanabe, H.; Mori, C.; Iguchi, T.; Miyatake, K. Effect of UV screens and preservatives on vitellogenin and choriogenin production in male medaka (Oryzias latipes). Toxicology 2003, 194, 43-50. [CrossRef]

54. Dambal, V.Y.; Selvan, K.P.; Lite, C.; Barathi, S.; Santosh, W. Developmental toxicity and induction of vitellogenin in embryo-larval stages of zebrafish (Danio rerio) exposed to methyl paraben. Ecotoxicol. Environ. Saf. 2017, 141, 113-118. [CrossRef] [PubMed]

55. Barra Caracciolo, A.; Topp, E.; Grenni, P. Pharmaceuticals in the environment: Biodegradation and effects on natural microbial communities. A review. J. Pharm. Biomed. Anal. 2015, 106, 25-36. [CrossRef] [PubMed]

56. Lishman, L.; Smyth, S.A.; Sarafin, K.; Kleywegt, S.; Toito, J.; Peart, T.; Lee, B.; Servos, M.; Beland, M.; Seto, P. Occurrence and reductions of pharmaceuticals and personal care products and estrogens by municipal wastewater treatment plants in Ontario, Canada. Sci. Total Environ. 2006, 367, 544-558. [CrossRef] [PubMed]

57. Montes-Grajales, D.; Fennix-Agudelo, M.; Miranda-Castro, W. Occurrence of personal care products as emerging chemicals of concern in water resources: A review. Sci. Total Environ. 2017, 595, 601-614. [CrossRef] [PubMed]

58. Rüdel, H.; Böhmer, W.; Müller, M.; Fliedner, A.; Ricking, M.; Teubner, D.; Schröter-Kermani, C. Retrospective study of triclosan and methyl-triclosan residues in fish and suspended particulate matter: Results from the German Environmental Specimen Bank. Chemosphere 2013, 91, 1517-1524. [CrossRef] [PubMed]

59. Sorensen, J.P.R.; Lapworth, D.J.; Nkhuwa, D.C.W.; Stuart, M.E.; Gooddy, D.C.; Bell, R.A.; Chirwa, M.; Kabika, J.; Liemisa, M.; Chibesa, M.; et al. Emerging contaminants in urban groundwater sources in Africa. Water Res. 2015, 72, 51-63. [CrossRef] [PubMed]

60. Perez, A.L.; De Sylor, M.A.; Slocombe, A.J.; Lew, M.G.; Unice, K.M.; Donovan, E.P. Triclosan occurrence in freshwater systems in the United States (1999-2012): A meta-analysis. Environ. Toxicol. Chem. 2013, 32, 1479-1487. [CrossRef] [PubMed]

61. Kim, Y.M.; Murugesan, K.; Schmidt, S.; Bokare, V.; Jeon, J.R.; Kim, E.J.; Chang, Y.S. Triclosan susceptibility and co-metabolism-a comparison for three aerobic pollutant-degrading bacteria. Bioresour. Technol. 2011, 102, 2206-2212. [CrossRef] [PubMed]

62. Silva, A.R.R.; Cardoso, D.N.; Cruz, A.; Lourenço, J.; Mendo, S.; Soares, A.M.V.M.; Loureiro, S. Ecotoxicity and genotoxicity of a binary combination of triclosan and carbendazim to Daphnia magna. Ecotoxicol. Environ. Saf. 2015, 115, 279-290. [CrossRef] [PubMed]

63. Kovacevic, V.; Simpson, A.J.; Simpson, M.J. 1H NMR-based metabolomics of Daphnia magna responses after sub-lethal exposure to triclosan, carbamazepine and ibuprofen. Comp. Biochem. Physiol. Part D Genom. Proteom. 2016, 19, 199-210. [CrossRef]

64. Orvos, D.R.; Versteeg, D.J.; Inauen, J.; Capdevielle, M.; Rothenstein, A.; Cunningham, V. Aquatic toxicity of triclosan. Environ. Toxicol. Chem. 2002, 21, 1338-1349. [CrossRef] [PubMed]

65. Kim, J.-W.; Ishibashi, H.; Yamauchi, R.; Ichikawa, N.; Takao, Y.; Hirano, M.; Koga, M.; Arizono, K. Acute toxicity of pharmaceutical and personal care products on freshwater crustacean (Thamnocephalus platyurus) and fish (Oryzias latipes). J. Toxicol. Sci. 2009, 34, 227-232. [CrossRef] [PubMed] 
66. Perron, M.M.; Ho, K.T.; Cantwell, M.G.; Burgess, R.M.; Pelletier, M.C. Effects of triclosan on marine benthic and epibenthic organisms. Environ. Toxicol. Chem. 2012, 31, 1861-1866. [CrossRef] [PubMed]

67. Xu, X.; Lu, Y.; Zhang, D.; Wang, Y.; Zhou, X.; Xu, H.; Mei, Y. Toxic Assessment of triclosan and triclocarban on Artemia salina. Bull. Environ. Contam. Toxicol. 2015, 95, 728-733. [CrossRef] [PubMed]

68. Lin, D.; Li, Y.; Zhou, Q.; Xu, Y.; Wang, D. Effect of triclosan on reproduction, DNA damage and heat shock protein gene expression of the earthworm Eisenia fetida. Ecotoxicology 2014, 23, 1826-1832. [CrossRef] [PubMed]

69. Gillis, J.D.; Price, G.W.; Prasher, S. Lethal and sub-lethal effects of triclosan toxicity to the earthworm Eisenia fetida assessed through GC-MS metabolomics. J. Hazard. Mater. 2017, 323, 203-211. [CrossRef] [PubMed]

70. Wang, X.; Liu, Z.; Wang, W.; Yan, Z.; Zhang, C.; Wang, W.; Chen, L. Assessment of toxic effects of triclosan on the terrestrial snail (Achatina fulica). Chemosphere 2014, 108, 225-230. [CrossRef] [PubMed]

71. Binelli, A.; Cogni, D.; Parolini, M.; Riva, C.; Provini, A. In vivo experiments for the evaluation of genotoxic and cytotoxic effects of triclosan in Zebra mussel hemocytes. Aquat. Toxicol. 2009, 91, 238-244. [CrossRef] [PubMed]

72. Martínez-Paz, P.; Morales, M.; Martín, R.; Martínez-Guitarte, J.L.; Morcillo, G. Characterization of the small heat shock protein Hsp27 gene in Chironomus riparius (Diptera) and its expression profile in response to temperature changes and xenobiotic exposures. Cell Stress Chaperones 2014, 19, 529-540. [CrossRef] [PubMed]

73. Martínez-Paz, P.; Morales, M.; Martínez-Guitarte, J.L.; Morcillo, G. Genotoxic effects of environmental endocrine disruptors on the aquatic insect Chironomus riparius evaluated using the comet assay. Mutat. Res. Toxicol. Environ. Mutagen. 2013, 758, 41-47. [CrossRef] [PubMed]

74. Martínez-Paz, P.; Morales, M.; Urien, J.; Morcillo, G.; Martínez-Guitarte, J.L. Endocrine-related genes are altered by antibacterial agent triclosan in Chironomus riparius aquatic larvae. Ecotoxicol. Environ. Saf. 2017, 140, 185-190. [CrossRef] [PubMed]

75. Xin, X.; Huang, G.; Liu, X.; An, C.; Yao, Y.; Weger, H.; Zhang, P.; Chen, X. Molecular toxicity of triclosan and carbamazepine to green algae Chlorococcum sp.: A single cell view using synchrotron-based Fourier transform infrared spectromicroscopy. Environ. Pollut. 2017, 226, 12-20. [CrossRef] [PubMed]

76. Rowett, C.J.; Hutchinson, T.H.; Comber, S.D.W. The impact of natural and anthropogenic Dissolved Organic Carbon (DOC), and $\mathrm{pH}$ on the toxicity of triclosan to the crustacean Gammarus pulex (L.). Sci. Total Environ. 2016, 565, 222-231. [CrossRef] [PubMed]

77. Park, J.C.; Han, J.; Lee, M.-C.; Seo, J.S.; Lee, J.-S. Effects of triclosan (TCS) on fecundity, the antioxidant system, and oxidative stress-mediated gene expression in the copepod Tigriopus japonicus. Aquat. Toxicol. 2017, 189, 16-24. [CrossRef] [PubMed]

78. Chai, L.; Chen, A.; Luo, P.; Zhao, H.; Wang, H. Histopathological changes and lipid metabolism in the liver of Bufo gargarizans tadpoles exposed to triclosan. Chemosphere 2017, 182, 255-266. [CrossRef] [PubMed]

79. González-Pleiter, M.; Rioboo, C.; Reguera, M.; Abreu, I.; Leganés, F.; Cid, Á.; Fernández-Piñas, F. Calcium mediates the cellular response of Chlamydomonas reinhardtii to the emerging aquatic pollutant triclosan. Aquat. Toxicol. 2017, 186, 50-66. [CrossRef] [PubMed]

80. Wang, C.-F.; Tian, Y. Reproductive endocrine-disrupting effects of triclosan: Population exposure, present evidence and potential mechanisms. Environ. Pollut. 2015, 206, 195-201. [CrossRef] [PubMed]

81. Lenz, K.A.; Pattison, C.; Ma, H. Triclosan (TCS) and triclocarban (TCC) induce systemic toxic effects in a model organism the nematode Caenorhabditis elegans. Environ. Pollut. 2017, 231, 462-470. [CrossRef] [PubMed]

82. Wyatt, L.H.; Luz, A.L.; Cao, X.; Maurer, L.L.; Blawas, A.M.; Aballay, A.; Pan, W.K.Y.; Meyer, J.N. Effects of methyl and inorganic mercury exposure on genome homeostasis and mitochondrial function in Caenorhabditis elegans. DNA Repair 2017, 52, 31-48. [CrossRef] [PubMed]

83. Xu, T.; Zhang, M.; Hu, J.; Li, Z.; Wu, T.; Bao, J.; Wu, S.; Lei, L.; He, D. Behavioral deficits and neural damage of Caenorhabditis elegans induced by three rare earth elements. Chemosphere 2017, 181, 55-62. [CrossRef] [PubMed]

84. Bailey, D.C.; Todt, C.E.; Orfield, S.E.; Denney, R.D.; Snapp, I.B.; Negga, R.; Montgomery, K.M.; Bailey, A.C.; Pressley, A.S.; Traynor, W.L.; et al. Caenorhabditis elegans chronically exposed to a Mn/Zn ethylene-bis-dithiocarbamate fungicide show mitochondrial Complex I inhibition and increased reactive oxygen species. Neurotoxicology 2016, 56, 170-179. [CrossRef] [PubMed] 
85. Negi, H.; Saikia, S.K.; Kanaujia, R.; Jaiswal, S.; Pandey, R. 3ß-Hydroxy-urs-12-en-28-oic acid confers protection against ZnONPs induced adversity in Caenorhabditis elegans. Environ. Toxicol. Pharmacol. 2017, 53, 105-110. [CrossRef] [PubMed]

86. Jacques, M.T.; Oliveira, J.L.; Campos, E.V.R.; Fraceto, L.F.; Ávila, D.S. Safety assessment of nanopesticides using the roundworm Caenorhabditis elegans. Ecotoxicol. Environ. Saf. 2017, 139, 245-253. [CrossRef] [PubMed]

87. Guo, X.; Li, Q.; Shi, J.; Shi, L.; Li, B.; Xu, A.; Zhao, G.; Wu, L. Perfluorooctane sulfonate exposure causes gonadal developmental toxicity in Caenorhabditis elegans through ROS-induced DNA damage. Chemosphere 2016, 155, 115-126. [CrossRef] [PubMed]

88. Meyer, D.; Williams, P.L. Toxicity Testing of Neurotoxic Pesticides in Caenorhabditis elegans. J. Toxicol. Environ. Health Part B 2014, 17, 284-306. [CrossRef] [PubMed]

89. Xiong, H.; Pears, C.; Woollard, A. An enhanced C. elegans based platform for toxicity assessment. Sci. Rep. 2017, 7, 9839. [CrossRef] [PubMed]

90. Tejeda-Benitez, L.; Flegal, R.; Odigie, K.; Olivero-Verbel, J. Pollution by metals and toxicity assessment using Caenorhabditis elegans in sediments from the Magdalena River, Colombia. Environ. Pollut. 2016, 212, 238-250. [CrossRef] [PubMed]

91. Höss, S.; Jänsch, S.; Moser, T.; Junker, T.; Römbke, J. Assessing the toxicity of contaminated soils using the nematode Caenorhabditis elegans as test organism. Ecotoxicol. Environ. Saf. 2009, 72, 1811-1818. [CrossRef] [PubMed]

92. Roh, J.-Y.; Park, Y.-K.; Park, K.; Choi, J. Ecotoxicological investigation of CeO2 and TiO2 nanoparticles on the soil nematode Caenorhabditis elegans using gene expression, growth, fertility, and survival as endpoints. Environ. Toxicol. Pharmacol. 2010, 29, 167-172. [CrossRef] [PubMed]

93. Shen, L.; Xiao, J.; Ye, H.; Wang, D. Toxicity evaluation in nematode Caenorhabditis elegans after chronic metal exposure. Environ. Toxicol. Pharmacol. 2009, 28, 125-132. [CrossRef] [PubMed]

94. Tejeda-Benitez, L.; Olivero-Verbel, J. Caenorhabditis elegans, a biological model for research in toxicology. Rev. Environ. Contam. Toxicol. 2016, 237, 1-35. [PubMed]

95. Höss, S.; Menzel, R.; Gessler, F.; Nguyen, H.T.; Jehle, J.A.; Traunspurger, W. Effects of insecticidal crystal proteins (Cry proteins) produced by genetically modified maize (Bt maize) on the nematode Caenorhabditis elegans. Environ. Pollut. 2013, 178, 147-151. [CrossRef] [PubMed]

96. Leelaja, B.C.; Rajini, P.S. Biochemical and physiological responses in Caenorhabditis elegans exposed to sublethal concentrations of the organophosphorus insecticide, monocrotophos. Ecotoxicol. Environ. Saf. 2013, 94, 8-13. [CrossRef] [PubMed]

97. Rui, Q.; Zhao, Y.; Wu, Q.; Tang, M.; Wang, D. Biosafety assessment of titanium dioxide nanoparticles in acutely exposed nematode Caenorhabditis elegans with mutations of genes required for oxidative stress or stress response. Chemosphere 2013, 93, 2289-2296. [CrossRef] [PubMed]

98. Smith, K.W.; Souter, I.; Dimitriadis, I.; Ehrlich, S.; Williams, P.L.; Calafat, A.M.; Hauser, R. Urinary paraben concentrations and ovarian aging among women from a fertility center. Environ. Health Perspect. 2013, 121, 1299-1305. [CrossRef] [PubMed]

99. Tejeda-Benítez, L.; Noguera-Oviedo, K.; Aga, D.S.; Olivero-Verbel, J. Toxicity profile of organic extracts from Magdalena River sediments. Environ. Sci. Pollut. Res. 2018, 25, 1-14. [CrossRef] [PubMed]

100. Altincicek, B.; Fischer, M.; Fischer, M.; Lüersen, K.; Boll, M.; Wenzel, U.; Vilcinskas, A. Role of matrix metalloproteinase ZMP-2 in pathogen resistance and development in Caenorhabditis elegans. Dev. Comp. Immunol. 2010, 34, 1160-1169. [CrossRef] [PubMed]

101. Anbalagan, C.; Lafayette, I.; Antoniou-Kourounioti, M.; Gutierrez, C.; Martin, J.R.; Chowdhuri, D.K.; De Pomerai, D.I. Use of transgenic GFP reporter strains of the nematode Caenorhabditis elegans to investigate the patterns of stress responses induced by pesticides and by organic extracts from agricultural soils. Ecotoxicology 2013, 22, 72-85. [CrossRef] [PubMed]

102. Power, R.S.; De Pomerai, D.I. Effect of single and paired metal inputs in soil on a stress-inducible transgenic nematode. Arch. Environ. Contam. Toxicol. 1999, 37, 503-511. [CrossRef] [PubMed]

103. Turbyville, T.J.; Wijeratne, E.M.K.; Whitesell, L.; Gunatilaka, A.A.L. The anticancer activity of the fungal metabolite terrecyclic acid A is associated with modulation of multiple cellular stress response pathways. Mol. Cancer Ther. 2005, 4, 1569-1576. [CrossRef] [PubMed] 
104. Wählby, C.; Lee Conery, A.; Bray, M.A.; Kamentsky, L.; Larkins-Ford, J.; Sokolnicki, K.L.; Veneskey, M.; Michaels, K.; Carpenter, A.E.; O'Rourke, E.J. High- and low-throughput scoring of fat mass and body fat distribution in C. elegans. Methods 2014, 68, 492-499. [CrossRef] [PubMed]

105. De Andrade, A.L.C.; Soares, P.R.L.; da Silva, S.C.B.L.; da Silva, M.C.G.; Santos, T.P.; Cadena, M.R.S.; Soares, P.C.; Cadena, P.G. Evaluation of the toxic effect of endocrine disruptor bisphenol A (BPA) in the acute and chronic toxicity tests with Pomacea lineata gastropod. Comp. Biochem. Physiol. Part C Toxicol. Pharmacol. 2017, 197, 1-7. [CrossRef] [PubMed]

106. Matsushima, A.; Ryan, K.; Shimohigashi, Y.; Meinertzhagen, I.A. An endocrine disruptor, bisphenol A, affects development in the protochordate Ciona intestinalis: Hatching rates and swimming behavior alter in a dose-dependent manner. Environ. Pollut. 2013, 173, 257-263. [CrossRef] [PubMed]

107. Ura, K.; Kai, T.; Sakata, S.; Iguchi, T.; Arizono, K. Aquatic acute toxicity testing using the nematode Caenorhabditis elegans. J. Health Sci. 2002, 48, 583-586. [CrossRef]

108. Dobbins, L.L.; Usenko, S.; Brain, R.A.; Brooks, B.W. Probabilistic ecological hazard assessment of parabens using Daphnia magna and Pimephales promelas. Environ. Toxicol. Chem. 2009, 28, 2744-2753. [CrossRef] [PubMed]

109. Tan, L.; Wang, S.; Wang, Y.; He, M.; Liu, D. Bisphenol A exposure accelerated the aging process in the nematode Caenorhabditis elegans. Toxicol. Lett. 2015, 235, 75-83. [CrossRef] [PubMed]

110. Zhou, D.; Yang, J.; Li, H.; Cui, C.; Yu, Y.; Liu, Y.; Lin, K. The chronic toxicity of bisphenol A to Caenorhabditis elegans after long-term exposure at environmentally relevant concentrations. Chemosphere 2016, 154, 546-551. [CrossRef] [PubMed]

111. Solecki, R.; Kortenkamp, A.; Bergman, Å.; Chahoud, I.; Degen, G.H.; Dietrich, D.; Greim, H.; Håkansson, H.; Hass, U.; Husoy, T.; et al. Scientific principles for the identification of endocrine-disrupting chemicals: A consensus statement. Arch. Toxicol. 2017, 91, 1001-1006. [CrossRef] [PubMed]

112. Pjanic, M. The role of polycarbonate monomer bisphenol-A in insulin resistance. PeerJ 2017, 5, 3809. [CrossRef] [PubMed]

113. Killeen, A.; Marin de Evsikova, C. Effects of sub-lethal teratogen exposure during larval development on egg laying and egg quality in adult Caenorhabditis elegans. F1000Research 2016, 5, 2925. [CrossRef] [PubMed]

114. Chen, Y.; Shu, L.; Qiu, Z.; Lee, D.Y.; Settle, S.J.; Que Hee, S.; Telesca, D.; Yang, X.; Allard, P. Exposure to the BPA-substitute bisphenol $S$ causes unique alterations of germline function. PLoS Genet. 2016, 12, e1006223. [CrossRef] [PubMed]

115. Han, Y.; Song, S.; Wu, H.; Zhang, J.; Ma, E. Antioxidant enzymes and their role in phoxim and carbaryl stress in Caenorhabditis elegans. Pestic. Biochem. Physiol. 2017, 138, 43-50. [CrossRef] [PubMed]

116. Braeckman, B.P.; Smolders, A.; Back, P.; De Henau, S. In Vivo detection of reactive oxygen species and redox status in Caenorhabditis elegans. Antioxid. Redox Signal. 2016, 25, 577-592. [CrossRef] [PubMed]

117. Avila, D.S.; Benedetto, A.; Au, C.; Bornhorst, J.; Aschner, M. Involvement of heat shock proteins on Mn-induced toxicity in Caenorhabditis elegans. BMC Pharmacol. Toxicol. 2016, 17, 54. [CrossRef] [PubMed]

118. Thondamal, M.; Witting, M.; Schmitt-Kopplin, P.; Aguilaniu, H. Steroid hormone signalling links reproduction to lifespan in dietary-restricted Caenorhabditis elegans. Nat. Commun. 2014, 5, 4879. [CrossRef] [PubMed]

119. Du, Z.-H.; Xia, J.; Sun, X.-C.; Li, X.-N.; Zhang, C.; Zhao, H.-S.; Zhu, S.-Y.; Li, J.-L. A novel nuclear xenobiotic receptors (AhR/PXR/CAR)-mediated mechanism of DEHP-induced cerebellar toxicity in quails (Coturnix japonica) via disrupting CYP enzyme system homeostasis. Environ. Pollut. 2017, 226, 435-443. [CrossRef] [PubMed]

120. Qin, L.; Du, Z.-H.; Zhu, S.-Y.; Li, X.-N.; Li, N.; Guo, J.-A.; Li, J.-L.; Zhang, Y. Atrazine triggers developmental abnormality of ovary and oviduct in quails (Coturnix coturnix) via disruption of hypothalamo-pituitary-ovarian axis. Environ. Pollut. 2015, 207, 299-307. [CrossRef] [PubMed]

121. Mimoto, A.; Fujii, M.; Usami, M.; Shimamura, M.; Hirabayashi, N.; Kaneko, T.; Sasagawa, N.; Ishiura, S. Identification of an estrogenic hormone receptor in Caenorhabditis elegans. Biochem. Biophys. Res. Commun. 2007, 364, 883-888. [CrossRef] [PubMed]

122. Montes-Grajales, D.; Olivero-Verbel, J. Computer-aided identification of novel protein targets of bisphenol A. Toxicol. Lett. 2013, 222, 312-320. [CrossRef] [PubMed] 
123. Xu, J.Y.; Wu, L.; Shi, Z.; Zhang, X.J.; Englert, N.A.; Zhang, S.Y. Upregulation of human CYP2C9 expression by Bisphenol A via estrogen receptor alpha $(\mathrm{ER} \alpha)$ and Med25. Environ. Toxicol. 2017, 32, 970-978. [CrossRef] [PubMed]

124. An, J.H.; Blackwell, T.K. SKN-1 links C. elegans mesendodermal specification to a conserved oxidative stress response. Genes Dev. 2003, 17, 1882-1893. [CrossRef] [PubMed]

125. Yoon, D.S.; Choi, Y.; Cha, D.S.; Zhang, P.; Choi, S.M.; Alfhili, M.A.; Polli, J.R.; Pendergrass, D.; Taki, F.A.; Kapalavavi, B.; et al. Triclosan disrupts SKN-1/Nrf2-mediated oxidative stress response in C. elegans and human mesenchymal stem cells. Sci. Rep. 2017, 7, 12592. [CrossRef] [PubMed]

126. Legeay, S.; Faure, S. Is bisphenol A an environmental obesogen? Fundam. Clin. Pharmacol. 2017, 31, 594-609. [CrossRef] [PubMed]

(C) 2018 by the authors. Licensee MDPI, Basel, Switzerland. This article is an open access article distributed under the terms and conditions of the Creative Commons Attribution (CC BY) license (http:/ / creativecommons.org/licenses/by/4.0/). 